\title{
Wacana Islam dan Negara Era Pra-Kemerdekaan: Pergulatan Ideologis Kelompok Islam dan Nasionalis Sekuler
}

\author{
Anjar Nugroho \\ Fakultas Agama Islam, Universitas Muhammadiyah Purwokerto. \\ Email:njr_nugroho75@gmail.com
}

\begin{abstract}
This article examines the debates between the Islamic group and secular nationalist group during pre Independence era on the the relationship between Islam and the state. The major factors stimulating the conflicts in conceiving the relationship between Islam and the state among Indonesian politicians was not about the disparity of the level of religiosity. Instead, it signifies the faiule of the political elites in reconciling different political views among Indoensians, as if Islam and nationalism are different and conflicting concepts. This article, therefore, discusses the ideas proposed by these two competing groups, Islamist and nationalist, and their ideological inclination. In particular, this article sees to what extent the Islamic group contributed to the state formation after Independence era.

Keywords: Islam, the state, secularnationalist, ideology.
\end{abstract}

\section{ABSTRAK}

Tulisan ini mengkaji tentang pertarungan ideologis semasa pra kemerdekaan antara kelompok nasionalis sekuler dan Islam tentanng wacana Islam dan negara. Tulisan ini berargumen bahwa diskursus idiologis tentang Islam dan negara yang memancing munculnya konflik di kalangan politisi tidak disebabkan oleh tingkat kesalehan keagamaan yang berbeda di kalangan umat Islam, tetapi, lebih disebabkan oleh ketidakmampuan elit politik nasional dalam mendamaikan berbedaan-perbedaan pandangan tersebut di atas, seakan-akan Islam dan nasionalisme merupakan dua entitas yang saling menegasikan. Tulisan ini mengelaborasi lebih dalam tentang gagasan-gagasan yang diusung oleh masing-masing kelompok yang "bertikai" untuk menegaskan keberpihakan politis-ideologis mereka. Kemudian digali pula tentang kontribusi kelompok Islam dalam menyusun konsep kenegaraan dan kebangsaan di kemudian hari (pasca kemerdekaan).

Kata Kunci: Islam, negara, nasionalis-sekuler, ideologi.

\section{PENDAHULUAN}

Hubungan politik antara Islam dan negara di Indonesia pada sebagian besar babakan sejarahnya merupakan cerita antagonisme dan kecurigaan antara satu dengan yang lainnya. Hubungan yang tidak harmonis ini terutama, tetapi tidak seluruhnya, disebabkan oleh perbedaan pandangan para pendiri republik ini - yang sebagian besarnya muslim - mengenai negara Indonesia merdeka yang dicita-citakan. Salah satu butir terpenting dalam perbedaan pendapat di atas adalah apakah negara ini bercorak "Islam" atau "nasionalis". Konstruk kenegaraan pertama mengharuskan agar Islam, karena sifatnya ynag holistik dan kenyataan bahwa agama itu 
dianut oleh sebagian besar penduduk, diakui dan diterima sebagai dasar idiologi negara. Tetapi atas pertimbangan bahwa Indonesia adalah negara yang secara sosial-keagamaan bersifat majemuk, maka - demi persatuan nasional - konstruk kenegaraan kedua menghendaki agar Indonesia didasarkan atas Pancasila, sebuah idiologi yang sudah didekonfessionalisasi ${ }^{11}$.

Kenyataan bahwa diskursus idiologis seperti itu memancing munculnya konflik, hal itu sebagian besar tidak disebabkan oleh tingkat kesalehan keagamaan yang berbeda di kalangan umat Islam - sebuah pandangan yang melandasi konsep-konsep seperti pemisahan santri-abangan dan Islam-sekuler (atau netral-agama) yang terkenal itu. Tetapi, hal itu terutama disebabkan oleh ketidakmampuan elit politik nasional dalam mendamaikan berbedaan-perbedaan pandangan tersebut di atas, seakan-akan Islam dan nasionalisme merupakan dua entitas yang saling menegasikan.

Jika konflik antara kelompok Islam (santri) dan nasionalis (abangan) dipotret pada era pra kemerdekaan, ranah konfliknya adalah dalam konteks perbedaan ideologi dasar perjuangan. Kelompok Islam menghendaki agar Islamlah yang dijadikan dasar idiologi perjuangan menghadapi kolonial, sedangkan nasionalis sekuler menghendaki dasar nasionalisme yang lepas dari Islam. Mereka menyebut kelompoknya sebagai golongan "kebangsaan” nasionalis sekuler, menuntut agar nasionalisme yang lepas dari paham agama manapun, yang harus dijadikan dasar ideologi perjuangan. Mereka, sebagaimana kalangan pragmatis pada umumnya menganggap agama pada dasarnya merupakan 'urusan pribadi dan individual”2), karena itu agama sulit memberikan dasar yang kokoh untuk suatu ideologi nasionalis yang mampu mengakomodasi dan mengintegrasikan seluruh kelompok suku, agama, dan ras yang beraneka ragam di Indonesia.

Di kalangan nasionalis sekuler terdapat keyakinan bahwa pengalaman historis dan kehendak hidup bersamalah yang dapat dijadikan dasar ideologi perjuangan bangsa. Mereka diilhami oleh perdapat Ernest Renan tentang pengertian "bangsa" (nation). Dalam salah satu tulisannya, Renan mengemukakan teori tentang pembentuk ideologi bangsa. Bangsa, menurut Renan, ialah suatu asas rohani, yang tumbul dari keadaan-keadaan historis yang tersusun secara mendalam ${ }^{3)}$.

Teori ideologi bangsa yang dikemukakan Renan, dalam dataran tertentu mempunyai relevansi dengan gejala timbulnya paham kebangsaan di Indonesia. Telah banyak pengorbanan bangsa Indonesia akibat penjajahan pihak asing. Penindasan kolonial asing ini, menurut Goerge Kahin, merupakan salah satu faktor penyebab timbulnya gagasan nasionalisme Indonesia ${ }^{4}$.

Terdapat perbedaan prinsip ideologis antara kedua golongan di atas telah menciptakan ketegangan di antara mereka. Ketegangan yang paling jelas terlihat pada retaknya hubungan tokoh-tokoh Sarekat Islam dengan tokoh-tokoh nasionalis sekuler.

Mengapa pergulatan ideologis antara kedua kelompok tersebut layak untuk dikaji? Setidaknya ada dua alasan untuk menjawab pertanyaan itu. Pertama, secara substansial perdebatan ideologis antara dua kelompok itu merefleksikan pertarungan ideologis yang tak kunjung usai dari sekitar tahun 1920 sampai 1945. Gagasan-gagasan yang dipolemikkan itu mendasar dan aktual, seperti masalah apakah agama harus 
disatukan atau dipisahkan dari politik, masalah prinsip kenegaraan yang bagaimana yang harus dijadikan dasar negara dan sekulerisasi politik dalam masyarakat berpenduduk mayoritas Muslim.

Polemik yang menyangkut berbagai ide dan tujuan ini mewarnai corak perkembangan politik, yang berkirar pada masalah peranan Islam, hubungan antara agama dan negara, corak nasionalisme, serta ideologi yang diperlukan dalam menata suatu negara kebangsaan (nation state).5)

Kedua, jika kedua kelompok itu dipersonifikasi, maka akan muncul dua tokoh pergerakan nasional yang mewakili masingmasing kelompok, dan secara terangterangan kedua tokoh itu saling berseteru. Mereka adalah Natsir, mewaliki kelompok Islam dan Soekarno mewakili kelompok nasionalis sekuler. Keduanya adalah tokoh politik paling legendaris dalam sejarah Indonesia kontemporer. Ada pertanyaan menarik yang ingin dijawab dalam kajian ini, mengapa polemik itu terjadi justru diantara dua kelompok dan dua tokoh pergerakan nasional, yang bila dikategorikan menurut terminologi Barat termasuk "manusia modern”. Mengapa justru Natsir yang mengoreksi dan mengkritisi gagasan-gagasan "modernisme Islam” Soekarno, yang kedua tokoh itu dikenal sebagai sama-sama modernis Muslim, yang berpendidikan maju (Barat). Tetapi yang jelas, polemik yang mereka bangun sangat berpengaruh terhadap corak dan konfigurasi politik Indonesia menjelang kemerdekaan sampai pasca kemerdekaan.

Setelah melihat selintas fenomena politik aktual Indonesia pra-kemerdekaan, yang melibatkan kelompok Islam dan nasionalissekuler sebagai "petarung" dalam perang ideologi mengenai konsep kebangsaan dan kenegaraan (nation-state), dapat dikerucutkan kajian ini pada tataran ; Pertama, gagasangagasan apa yang diusung oleh masing-masing kelompok yang "bertikai" untuk menegaskan keberpihakan politis-ideologis mereka; Kedua, apakah gagasan kedua belah pihak tidak menemukan titik kompromi (kalimah sawa') dalam rangka membangun sintesa sistem politik Indonesia yang dicita-citakan bersama, dalam kata lain apakah tidak ada kontribusi Islam dalam menyusun konsep kenegaraan dan kebangsaan di kemudian hari (pasca kemerdekaan).

\section{ISLAM DAN NASIONALISME: SEBUAH PERDEBATAN AWAL}

Selama dekade awal abad 20, gagasan nasionalisme merupakan fokus perdebatan politik yang paling seru di dunia Islam. ${ }^{13)}$ Sejumlah intelektual muslim tidak setuju dengan gagasan tersebut dengan alasan prinsip kedaulatan rakyat bertentangan dengan prinsip hukum Tuhan dan prinsip ummah (universe Islamic community). Penyair dan filosof asal Pakistan, Muhammad Iqbal, misalnya, menegaskan bahwa Islam menghendaki satu kesatuan umat Islam yang tidak terbatas, dan menyebut kolonialisme Barat sebagai biang keladi hancurnya persatuan dunia Islam. Walau demikian, sebagaimana rekan-rekan sejamannya, Iqbal pada akhirnya sadar bahwa upaya membangun kembali satu bentuk komunitas politik umat Islam yang bersifat universal sudah tidak mungkin lagi, dan karena itu masing-masing wilayah umat Islam harus berjuang meraih dan mempertahankan kemerdekaannya. ${ }^{14)}$

Hingga saat ini, sejumlah kecil umat Islam nonkonformis masih tetap menentang 
prinsip negara yang menurut mereka lebih menundukkan kehendak manusia di atas kedaulatan Tuhan. Kendati demikian, seperti dikemukakan James Piscatori, kecenderungan umum pada abad 20 ini bagi umat Islam adalah menerima legitimasi negara-bangsa (state-nation) dan mengarahkan politik mereka dalam konteks negara-kebangsaan tersebut. ${ }^{15)}$

Untuk kasus Indonesia, penerimaan (reception) ide-ide nasionalisme pada era perjuangan melawan kolonialisme, sangat menarik untuk dikaji. Gerakan-gerakan masyarakat pribumi yang sebagian besar disponsori kalangan Islam bersendikan semangat nasionalisme untuk menentang kolonialisme Belanda. Sehingga para pengkaji perkembangan nasionalisme di Indonesia mencatat, Islam memainkan peranan yang sangat menentukan dalam upaya ini. Islam berfungsi sebagai mata rantai yang menyatukan rasa persatuan nasional menentang kolonial. "Agama Muhammad", tulis Goerge Kahin dalam karya klasiknya, Nationalism and Revolution in Indonesia, "bukan saja merupakan mata rantai yang mengikat tali persatuan, melainkan ia merupakan simbol kesamaan nasib (ingroup) menentang penjajahan asing dan penindas yang berasal dari agama lain”. ${ }^{16)}$ Atau sebagaimana dikemukakan Fred R. von der Mahden dalam disertasi doktornya "Islam and the Rise of Nationalism in Indonesia": "Islam merupakan sarana yang paling jelas baik untuk membangun rasa persatuan nasional maupun untuk membedakan masyarakat Indonesia dari kaum penjajah Belanda .... Oleh karena itu, karena terdiri dari berbagai tradisi historis, linguistik, kultural dan bentuk geografis yang berbeda, maka satu-satunya ikatan universal yang tersedia, di luar kekuasaan kolonial, adalah Islam”. ${ }^{17)}$
Islam dan nasionalisme dalam tataran itu menjadi satu keping mata uang yang berguna untuk membangun semangat perjuangan anti kolonialisme oleh negara asing. Akan tetapi tidak serta merta semua golongan Islam, paling tidak saat itu, menerima idiologi nasionalisme yang genuin part-nya dari Barat, yang membawa gerbong besar tentang gagasan kebangsaan dan kewarganegaraan modern. Dalam konteks dunia Islam, lebih dari seabad umat Islam bergumul dengan persoalan bagaimana mempertemukan politik Islam dengan gagasan kebangsaan dan kewarganegaraan. Ini kian terbukti pada akhir abad 20 dalam pertarungan antara nasionalisme sekuler dan nasionalisme Islam. ${ }^{18)}$

Di Indonesia, arena perdebatan selama abad 20 adalah menyangkut persoalan dalam konteks gagasan dan praktik berbangsa. Organisasi massa modern pertama, Sarekat Islam (S1), didirikan oleh H. Samanhoedi di Solo tanggal 11 November 1912, ditujukan untuk mengangkat hak-hak politik kaum pribumi, yang dengan cepat memperoleh jumlah pengikut yang besar di Nusantara, khususnya di Jawa. ${ }^{19)}$ Kandati demikian, SI tenggelam dalam persoalan bagaimana peranan Islam dalam konteks negara kebangsaan.

Bahwa SI merupakan organisasi politik nasional yang pertama, hal itu tidak hanya disebabkan oleh agendanya yang bersifat nasional, yakni menyerukan kemerdekaan Indonesia. Untuk sebagian besar, hal itu juga disebabkan oleh kemampuannya dalam menghimpun dukungan massa yang mengatasi pengelompokan-pengelompokan sosial dalam masyarakat. ${ }^{20)}$ Seperti dikatakan Benda, bahwa dengan menampilkan diri secara penuh kepada rakyat Indonesia, SI 
memperoleh dukungan dari berbagai kelas, di kota-kota dan di desa-desa. Para pedagang muslim, para buruh di kota-kota, kyai dan ulama, bahkan juga kalangan priyayi, tetapi di atas segalanya seluruh petani, bergabung dalam gerakan politik berbasis massa yang pertama - dan terakhir - pada masa kolonialisme di Indonesia. ${ }^{21)}$

Namun sangat disayangkan bahwa posisi yang tengah menjulang ini tidak dapat dipertahankan. Peran pentingkan sebagai katalisator pergerakan nasional Indonesia mulai memudar di penghujung 1920-an. Terlepas dari upaya para pemimpin dan aktivisnya untuk memegang kembali kemudi kepemimpinan nasional di kemudian hari, SI gagal mempertahankan kepeloporannya yang menonjol dalam mencapai kemerdekaan. Sebaliknya di tahun-tahun berikutnya, idealisme dan aktivisme politiknya dibayangbayangi kelompok-kelompok politik sosial lain yang tidak secara formal menyatakan Islam sebagai dasar ideologinya. ${ }^{22)}$

Merosotnya peran SI ini disebabkan oleh beberapa faktor. Faktor utamanya adalah ketidakmampuan para pemimpin dan aktivisnya SI mengatasi berbagai perbedaan paham di antara mereka, khususnya yang berkaitan dengan soal arah politik SI, terutama lagi setelah Marxisme dibawa masuk ke dalam organisasi itu. ${ }^{23)}$ Dari sinilah pertarungan idiologis antara pendukung politik Islam konvensional vis a vis kelompok yang cenderung beraliran idiologi Marxisme dan nasionalis sekuler di mulai. ${ }^{24)}$ Tiga serangkai, Tjokroaminoto, Agus Salim, dan Abdul Moeis dengan tegas menyatakan bahwa Islam adalah idiologi partai itu, dan mereka menggerakkan partai itu sejalan dengan geraka Pan-Islamisme di Timur Tengah. Sebaliknya, Semaun dan Darsono lebih menghendaki "disingkirkannya" agama dari politik, seraya mengorientasikan diri mereka serta seluruh kegiatan partai kepada prinsip-prinsip Marxis. ${ }^{25)}$

Tepatnya pada tahun 1921, pertentangan antara kedua faksi ini sampai pada tahap yang kritis dengan terpentalnya wakil-wakil sayap kiri dari SI. ${ }^{26)}$ Pada masa lima tahun berikutnya, kalangan kiri (atau lebih dikenal dengan sebutan "SI Merah") dan kubu Islam (dikenal dengan sebutan "SI Putih"), bersaing menguasai cabang-cabang SI lokal. Beriring dengan kian mengerasnya represi negara yang bertambah kuat, persaingan tersebut membuat SI jadi terpecah-pecah, dan membuat berantakan perjuangan kaum pribumi dalam merebut kemerdekaan. ${ }^{27)}$

Perpecahan di atas, menjadikan SI kurang menarik bagi kalangan intelektual yang lebih muda dan terdidik secara Barat. Salah satu diantaranya adalah Soekarno, anak-didik Tjokroaminoto, yang meutuskan untuk membentuk organisasi politik sendiri - Partai Nasional Indonesia (PNI) - pada tahun 1927 dan mengembangkan faham ideologi-politik yang berbeda. Seperti organisasi-organisasi nasionalis lain, tujuan PNI adalah menyempurnakan kemerdekaan Indonesia, baik ekonomi maupun politik, dengan pemerintahan yang dipilih oleh dan bertanggung jawab kepada seluruh rakyat Indonesia. ${ }^{28)}$ Didorong oleh gagasan mengenai persatuan seluruh rakyat Indonesia dalam mencapai kemerdekaan, partai ini mendasarkan kiprah nasionalisnya kepada paham ideologi kebangsaan (nasionalisme). Meski seorang Muslim, Soekarno berkali-kali menegaskan bahwa partai tersebut tidak dapat mendasarkan diri kepada ideologi Islam. Baginya, inilah pilihan terbaik untuk kemerdekaan maupun masa depan rakyat 
Indonesia baik yang muslim maupun non muslim. ${ }^{29)}$

Sejak tahun 1930-an dan selanjutnya, kelompok ini, bersama beberapa intelektualaktivis didikan Barat lain yang baru kembali dari Belanda (terutama Sjahrir dan Muhammad Hatta), membentuk cikal bakal gerakan nasionalis di Indonesia. Dengan faham kebangsaan (nasionalisme) sebagai kekuatan utama, mereka mondominasi dan mengarahkan derap gerakan nasionalis Indonesia menuju kemerdekaan. Yang terjadi kemudian adalah, gerakan nasionalis ini, dalam kadar yang lebih besar dibandingkan ketika berhadapan dengan Marxisme sebelumnya membangun panggung konfrontasi ideologis antara para pemimpin dan aktivis Islam politik dan pesaing-pesaing mereka yang berpaham nasionalis, terutama dalam soal hubungan antara agama (Islam) dan negara dalam sebuah negara Indonesia yang merdeka. Dalam konteks historis inilah dua kelompok yang saling bertentangan muncul dalam diskursus politik Indonesia ; yaitu golongan Islam dan golongan Nasionalis. ${ }^{30}$

Sebelum kajian ini memotret dan mengulas labih dalam perdebatan ideologis antara golongan Islam (lebih banyak nantinya diwaliki oleh Muhammad Natsir) dan golongan nasionalis (diwakili oleh Soekarno), akan dipaparkan lebih dulu peran politikkultural gerakan-gerakan Islam non politik semisal Muhammadiyah dan Nahdhatul Ulama. Pemaparan ini lebih dimaksudkan untuk memperkaya dan memperluas spektrum historis perkembangan nasionalisme di Indonesia. Mengapa Muhammadiyah dan NU? Jawaban singkatnya adalah karena kedua organisasi itu telah muncul berbarengan dengan hiruk pikuk perjuangan melawan kolonialisme asing, dan kedua organisasi itu terlibat walau terbatas - dalam perdebatan ideologis paham kebangsaan yang nantinya muncul dekonfesionalisasi atas faham kebangsaan nasional, dan lagi-lagi kedua organisasi massa Islam itu memainkan peran politiknya.

\section{MUHAMMADIYAH DAN NU: BERSATU DALAM MIAI}

Muhammadiyah sebagai organisasi sosialkeagamaan, didirikan pada tanggal 18 November 1912 di Yogyakarta oleh KHA.

Dahlan sebagai jalan terobosan membangkitkan kesadaran bangsa Indonesia dari kebodohannya. Kebangkitan ini mempunyai dampak yang luas, sehingga menggerakkan lahirnya organisasi sejenis dari kalangan umat Islam ; Persyarikatan Ulama di Majalengka (1915), Persatuan Islam di Bandung (1923), Nahdhatul Ulama di Surabaya (1926), dan al-Washliyah di Medan (1930). ${ }^{31)}$

Orientasi gerakan Muhammadiyah adalah sosial-kemasyarakatan termasuk di dalamnya pendidikan, atau yang lebih dikenal dengan istilah perjuangan kultural (sebagai keping lain atas perjuangan struktural/politik formal). Robert W. Hefner ${ }^{32)}$ mencatat prestasi yang sangat sukses dari apa yang telah dilakukan Muhammadiyah dengan mengatakan bahwa Muhammadiyah telah mensintesiskan antara modernisme Islam dengan modernisme Barat dalam gerakangerakan sosialnya, khususnya dalam bidang pendidikan. Hefner labih lanjut mengatakan, bahwa Muhammadiyah tidak sekalipun pernah menunjukkan penolakannya, seperti kalangan Muslim tradisionalis, terhadap pendidikan, teknologi, dan ilmu pengetahuan yang berbau Barat. 
Muhammadiyah adalah organisasi modernis, dan secara kelembagaan Muhammadiyah juga menentang kalangan tradisionalis yang menekankan kepemimpinan keagamaan yang karismatik. Sebaliknya Muhammadiyah mengembangkan model organisasi yang berdasarkan pada sistem birokrasi yang teratur rapi dan pemilihan yang terbuka.

Berbeda dengan Muhammadiyah yang proses kelahirannya sampai usia dewasanya besar dan berkembang di rumah kultural, Nahdhatul Ulama terlahir sebagai organisasi politik pada zamannya. ${ }^{33)}$ Sebelum NU benarbenar lahir kelak pada tanggal 31 Januari 1926 di Surabaya, telah muncul organisasi, yang lebih berbau politik, yaitu Nahdhatul Wathan (1916). Nahdhatul Wathan inilah embrio dari gerakan Islam yang bernama Nahdhatul Ulama yang corak gerakannya lebih kurang sama ; yakni, sebagai respon atas persoalan kebangsaan dan memberi jawaban politik atas nasib yang menimpa bangsanya, bukan sebagai jam'iyah yang minus politik.

Nahdhatul Ulama pada sisi lain adalah antitesis atas gerakan modernisme

Muhammadiyah yang lebih dulu berdiri. Pada dataran grass-root, massa Muhammadiyah dan NU seringkali dalam banyak kasus "bertikai" dalam persoalan-persoalan teknis keagamaan (furu'iyyah). Sangat bisa jadi kondisi "konfliktual" ini sengaja "diciptakan" oleh pihak kolonial untuk mengebiri kekuatan potensial gerakan Islam melawan kolonialisme. ${ }^{34)}$

Perdebatan furu' antara Muhammadiyah dan NU cukup lama terjadi (yang sisa-sisanya masih ada sampai hari ini), dengan memakan waktu sekiran sebelas tahun, yakni antara tahun 1926-1937. Baru pada tahun 1937 terjalinlah kerjasama Muhammadiyah - NU dalam Majelis Islam A’la (luhur) Indonesia atau disingkat MIAI. Langkah ini pertanda kedewasaan pemimpin kedua organisasi Islam dalam menghadapi kenyataan perjuangan bangsa. Salah satu isu gerakan yang diangkat bersama dalam MIAI antara Muhammadiyah-NU adalah respon terhadap intervensi Pemerintah Belanda terhadap Hukum Islam di bidang perkawinan dengan memberlakukan Rancangan UndangUndang Perkawinan (1937). ${ }^{35)}$

Keterlibatan Muhammadiyah secara signifikan dalam MIAI, setidaknya menggeser orientasi gerakannya dari culture movement menjadi lebih agak politis. Dan salah satu yang mendorong pimpinan Muhammadiyah saat itu (KH. Mas Mansur) menggeser orientasi gerakan Muhammadiyah adalah kenyataan eksternal di mana kekuatankekuatan partai politik melemah di tengah situasi dan suhu politik yang kian memanas dan membutuhkan masin politik baru untuk mensikapinya. Tingginya konflik antar kekuatan politik saat itu telah menimbulkan tarikan sentrifugal, yakni kebutuhan untuk saling memperoleh dukungan dan berafiliasi. Inilah yang mendorong Muhammadiyah terpanggil untuk terjun ke dalam aktifitas politik yang lebih kongkret (praktis). Peristiwa tersebut - mengutip MT Arifin - mempunyai arti yang sangat penting dalam perkembangan Muhammadiyah, karena kepemimpinan Mas Mansur telah berhasil meletakkan konvensi partisipasi politik Muhammadiyah di pentas politik nasional dan kemudian menjadi tradisi yang berlaku untuk masa-masa berikutnya. ${ }^{36)}$

Dalam perkembangan lebih lanjut, beberapa organisasi Islam turut bergabung dalam MIAI, misalnya Partai Islam Indonesia (PII), al-Irsyad, Persis dan lain-lain. PSII adalah organisasi Islam selain Muhammadiyah dan 
NU yang turut mendirikan MIAI. Tetapui tidak dapat disangkal, bahwa MIAI tidaklah lebih dari sekedar federasi yang sistem organisasinya begitu longgar, sukarela dan bukan suatu kesatuan aksi yang berdisiplin kuat. Dalam kenyataannya, perbedaanperbedaan antara kelompok pendukung aliansi yang reformis-modernis

(Muhammadiyah) dan ortodoks-tradisional $(\mathrm{NU})^{37)}$ tetap berlanjut. Tetapi bukan berarti keberadaan MIAI tidak penting dalam konteks sosial-politik saat itu. Harry J. Benda, mengingatkan untuk tidak meremehkan eksistensi MIAI. MIAI, begitu kata Benda, didukung oleh dua organisasi agama bermassa besar dan riil yang berpotensi dapat berbicara banyak dalam kontelasi sosialpolitik saat itu, disaat partai Sarekat Islam menghadapi saat-saat krisisnya. ${ }^{38)}$

MIAI juga hadir untuk memecahkan kebekuan dialogis antara kubu Islam dan nasionalis. Apalagi sejak Soekarno dan tokohtokoh nasionalis non-kooperatif diasingkan ke luar Jawa oleh pemerintah kolonial, peran organisasi pendukung MIAI semakin signifikan. Terakhir yang dapat dipotret dari keterlibatan organisasi pendukung MIAI, adalah peran yang dimainkannya dalam era pasca perang dunia kedua. Di saat itu, semangat untuk melepaskan diri dari penjajahan semakin berkobar, dan yang ada dalam pikiran elemen-elemen pendukung Indonesia merdeka adalah bagaimana menyatukan visi dan langkah agar gerakan pro-kemerdekaan bisa berjalan dengan efektif. Di sinilah bertemu momentumnya, kelompok nasionalis dan agamis (Islam), kooperatif dan non-kooperatif dapat bersatu dalam bentuk nasionalisme baru yang khas Indonesia. Dan lagi-lagi Benda mencatat, ${ }^{39)}$ nasionalisme itu sangat diwarnai oleh sentuhan-sentuhan nilai-nilai religiusitas (dalam hal ini berasal dari Islam) sehingga Muhammad Hatta menyebut nasionalisme religius.

\section{PERTARUNGAN IDEOLOGIS KELOMPOK ISLAM DAN KELOMPOK SEIKULER}

Pada awalnya, benturan antara kedua kelompok ini berlangsung di sekitar wasalah watak nasionalisme. Dalam upaya menemukan ikatan bersama untuk mencapai kemerdekaan Indonesia, Soekarno secara luas mendefinisikan nasionalisme sebagai "cinta kepada tanah air, kesediaan yang tulus untuk membaktikan diri dan mengabdi kepada tanah air, serta kesediaan untuk mengesampingkan kepentingan golongan yang sempit". ${ }^{40)}$ Di tempat lain, Soekarno menulis, bahwa nasionalisme adalah keyakinan, kesadaran di kalangan rakyat, bahwa mereka bersatu dalam satu kelompok, satu bangsa. ${ }^{41)}$

Bagi seorang pemimpin dan aktivis Islam politik seperto Agus Salim, pernyataan di atas sama saja artinya dengan mengangkat nasionalisme ke posisi yang setingkat dengan agama. Jika diikuti, tambahnya, maka pandangan itu akan memperbudak manusia menjadi penyembah tanah air. Jika demikian adanya, maka akibat-akibatnya akan sangat jauh. Pandangan ini akan dapat, masih kata Agus Salim, mencairkan keyakinan tauhid seseorang dan mengurangi bakti seseorang kepada Tuhan. ${ }^{42)}$ Karena alasan itu, Agus Salim dengan tegas menyatakan bahwa nasionalisme harus diletakkan dalam kerangka pengabdian manusia kepada Allah. Dan sejalan dengan itu, menurutnya, maka prinsip yang harus dinomorsatukan adalah Islam. ${ }^{43)}$

Ahmad Hasan, pemimpin organisasi 
reformis Persatuan Islam (Persis), mengkritik nasionalisme sebagai sesuatu yang berwatak chauvinistik. Menurutnya, posisi nasionalistik seperti itu sebanding dengan paham orangorang Arab mengenai chauvinistik kesukuan ('ashabiyah) sebelum datangnya Islam. Hal itu dilarang dalam Islam, karena praktik itu akan menjadi dinding pemisah antara sesama umat Islam di (yakni antara umat Islam di Indonesia dengan umat Islam lain di belahan dunia). Akhirnya dia juga memandang bahwa kelompok nasionalis sudah tentu tidak menjalankan hukum-hukum Islam, karena kelompok itu perlu netral terhadap agama, yaitu tidak boleh mengambil salah satu agama untuk dijadikan asas pemerintahan kelak. ${ }^{44)}$

Seperti gurunya (Ahmad Hasan), Muhammad Natsir juga mengkhawatirkan bergulirnya faham nasionalisme Soekarno menjadi suatu bentuk 'ashabiyah baru. Paham ini dalam pandangannya, dapat berujung kepada "fanatisme", yang memutuskan tali ukhuwah yang mengikat seluruh umat muslimin dari pelbagai bangsa. Bagi Natsir, paham nasionalisme harus didasarkan kepada niat yang suci, ilahiyah dan melampui hal-hal yang bersifat material. ${ }^{45)}$ Natsir juga percaya bahwa naionalisme harus bercorak Islami. Untuk alasan itu, ia memperkenalkan gagasan kebangsaan Islam. Ia mendasarkan keyakinan ini kepada kenyataan historis bahwa Islam-lah yang pada awalnya mendefinisikan nasionalisme Indonesia. Dalam kesempatan lain, Natsir bahkan menegaskan, bahwa tanpa Islam, nasionalisme Indonesia itu tidak akan ada, karena Islam yang pertama telah menanamkan benih-benih persatuan Indonesia, dan telah menghapuskan sikap-sikap isolasionis pulau-pulau yang beragam. ${ }^{46)}$
Pandangan Nasionalisme Soekarno yang konfessional itu dilalarbelakangi oleh pengalaman perguruan tingginya di lingkungan kolonial yang plural. Ia mirip seorang "fungsionaris kreol" (creole fungsionary), seperti telah diidentikkan oleh Benedict Anderson, dalam bukunya tentang nasionalisme yang banyak dibaca, sebagai prototype nasionalis (sekuler). ${ }^{47)}$

Berpengalaman sebagai pegawai pemerintah kolonial yang saat itu kian membutuhkan pegawai pribumi, Soekarno tertarik dengan gagasan-gagasan pencerahan Eropa dan gagasan-gagasan liberalisme-sosialis. Seperti kalangan pribumi lainnya, pengalaman ini mengantarkannya untuk menganut satu konsep tentang bangsa yang melampui basis etnisitas, wilayah dan agama. ${ }^{48)}$

Soekarno berpandangan, bahwa "Islam sejarah”, seperti disebutkannya, telah menyimpang dari orisinalitas agama Islam, sehingga membuat nasib umat Islam lebih buruk dibandingkan dengan Barat. Terpengaruh oleh kalangan reformis nasionalis sekuler di Turki dan Timur Tengah, Soekarno muda meyakini bahwa penyatuan agama dan negara dalam pemerintahan Islam tradisional ikut andil terhadap kemandegan dunia Islam. ${ }^{49)}$ Menurutnya, pemisahan Islam dari negara akan membebaskan Islam dari perilaku para penguasa yang korup dan bisa membangkitkan kekuasaan progresifnya. Dalam mengetengahkan soal ini, Soekarno muda berusaha keras untuk menunjukkan dirinya bukan sebagai seorang sekuler yang menentang ajaran-ajaran Islam. Sebaliknya dalam pandangannya, "ketidakterlembagakannya agama" (religious disestablishment) akan memberikan ruang bagi agama untuk merealisasikan dirinya secara 
lebih efektif dalam masyarakat.

Soekarno mengelaborasi gagasannya lebih dalam dengan mengambil pemikiran seorang ulama al-Azhar (kairo), Syekh Ali Abd al-

Raziq tentang pemisahan agama dan negara (sekulerisasi politik). Al-Raziq ${ }^{49)}$ sendiri berangkat dari asumsi atau pengandaian bahwa kekuasaan harus dicari sebab-sebab alamiyah, Raziq membangun klaim hubungan agama dan politik melalui perspektif sekuleristik. Klaim tentang khilafat dan kekuasaan dalam Islam itu ia mulai dengan mengajukan pertanyaan besar: (1) Apakah kekhalifahan memang diperlukan? (2) Apakah memang ada sistem pemerintahan yang Islami? (3) Dari manakah sumber legitimasi kekuasaan, dari atas (Tuhan) atau dari bawah (rakyat)?

Pertanyaan ini muncul di tengah seting sosial saat itu yang ditandai dengan lemahnya kekhalifahan dalam Islam, tetuama di kawasan Eropa Timur, yang kemudian memicu ketegangan di kalangan aktifis politik Islam. Ketegangan atau konflik itu di Turki berujung dengan pembubaran kekhalifahan Ottoman (Utsmaniyah) pada tahun 1923/1924 oleh pemerintah Turki di bawah kepemimpinan Kemal Ataturk. Pembubaran itu dilakukan dengan alasan lembaga spiritual saat itu, khususnya lembaga keulamaan, dinilai hanya mengabdi kepda kepentingan sultan/khalifah, menjustifikasi penguasa, dalam hal ini khalifah, tanpa memperhatikan berbagai kelemahan yang dimilikinya.

Di tengah melemahnya sistem khilafah antara lain karena disebabkan mengemukannya kepentingan pribadi penguasa seperti itulah, Raziq lalu membangun argumentasinya tentang kekuasaan. Menurutnya masyarakat memang memerlukan kekuasaan politik, namun tidak harus dalam bentuk tertentu. Bahkan umat pun tidak harus dipersatukan secara politik. Tesis utama Raziq dapat dikemukakan sebagai berikut:

(1) Bahwa Nabi tidak membangun negara danotoritasnya murni bersifat spiritual. (2) Bahwa Islam tidak menentukan sistem pemerintahan yang definitive. Karena itu umat Islam bebas memilih bentuk pemerintahan apapun yang mereka rasakah cocok (3) Bahwa tipe-tipe pemerintah yang dibentuk setelah wafatnya Nabi tidak memiliki dasar dalam doktrin Islam. Sistem itu sematamata diadopsi oleh orang-orang Arab dan dinaikkan derajatnya dengan istilah khilafah untuk memberi legitimasi religius. (4) Bahwa sistem ini telah menjadi sumber tipuana bagi sebagian besar persoalan dunia Islam, karena ia digunakan untuk melegitimasi tirani dan menimbulkan dekadensi umat Islam. ${ }^{50)}$

Menurut Raziq, persyaratan yang dibangun untuk menjustifikasi penyatuan agama dan politik dalam Islam didasarkan kepada tradisi pemikiran skripturalistik, idealistik dan formalistik dalam memahami teks doktrinal agama. ${ }^{51)}$ Dalam pemikiran skpritualistik pemahaman agama dilakukan secara tekstual. Pemikir seperti Sayyid Qutb, misalnya mengartikan secara harfiah ayat Alqur'an: "Barangsiapa yang tidak memutuskan menurut apa yang diturunkan Allah, maka mereka itu adalah orang-orang yang kafir". (QS. $5: 44,45,47)$

Ayat ini difahami kaum skripturalis sebagai perintah menjalankan pemerintahan illahi dalam lembaga formal sehingga lalu memunculkan konsep negara teokratis, dengan simbol-simbol kekuasaan bersumber dari Islam. Dengan demikian dalam 
memahami kekuasaan, penganut perpsektif skripturalis cenderung berangkat dari asumsi descending of power, dalam hal ini legitimasi penguasa berasal dari Tuhan, dan dengan demikian penguasa tidak lain adalah representasi dari kekuasaanNya yang dari sini lalu muncul pemerintahan teokratis. ${ }^{52)}$

Dalam membangun tesis pemisah agama dan politik Raziq, menghidarkan diri dari pemikiran skriptualistik, idealistik maupun formalistik. Raziq menegaskan bahwa tidak ada rujukan yang dapat dipakai di dalam alQur'an maupun Hadits untuk membuktikan adanya persyaratan menggerakan sistem kekhalifahan. Peraturan tentang kekuasaan politik, politheisme, perbudakaan atau tentang apapun tidak lantas menjadi wajib hanya karena dibahas dalam al-Qur'an. Dalam al-Qur'an yang sangat terkenal, "patuhlah kepada Allah, Rasul dan ulil amri, " tidak dengan serta merta merujuk kepada penguasa politik baru manapun. ${ }^{53)}$

Dengan mengacu pada mufassir seperti Baidhawi dan Zamakhsyari, Raziq menyatakan bahwa kata-kata ulil amri ditafsirkan sebagai "sahabat Nabi," atau "ulama' Oleh karena itu ia membantah bahwa Nabi Muhammad telah membentuk negara Islam di Madinah. Nabi hanya Rasulullah, bukan raja ataupun pemimpin politik. Ia menyatakan:

Muhammad hanyalah seorang utusan (Allah).

Ia betul-betul mengabdikan dirinya bagi dakwah agama tanpa kecenderungan yang menyangkut kedaulatan yang sementara sifatnya, karena ia tidak menyerukan bagi sesuatu yang berkaitan dengan pemerintahan.... Nabi tidak memiliki kerajaan ataupun pemerintahan yang sifatnya temporal. Ia tidak mendirikan kerajaan dalam pengeritan politik atau apa pun yang sinomim dengannya;... Ia hanyalah seorang Nabi, seperti Nabi-nabi yang lain yang mendahuluinya. Ia bukanlah raja atau pun pembangun negara, Ia juga tidak menyerukan bagi dibangunnya imperium temporal ${ }^{54)}$

Kembali kepada pemikiran Soekarno, dengan adanya pemisahan agama dari negara, menurut ia, tidak dengan sendirinya ajaran Islam dikesampingkan, sebab rakyat dapat memasukkan Islam ke dalam kebijakan politik negara melalui Dewan Perwakilan Rakyat (DPR). Soekarno meyakini demokrasi sebagai alternatif bagi negara, bila timbul masalah pemisahan agama dan negara. Menurutnya, dalam negara demokrasi ini, semua kelompok agama dituntut menguasai parlemen, sebab bila mereka menguasai lembaga itu, secara otomatis menguasai negara. ${ }^{55)}$

Sistem pemerintahan "negara agama” menurut Soekarno merupakan sistem pemerintah caesaro papisme. Dalam kasus Turki, sistem pemerintahan ini dijalankan oleh ulama di bawah pimpinan Syeikh alIslam, yang pada akhirnya melahirkan dualisme pemerintahan yang menghambat dan melemahkan negara Turki selama berabad-abad. Lebih lengkap Soekarno menulis:

"... maka ternyatalah bahwa sistem dualisme di dalam pemerintahan itu adalah selalu menjadi rem dan penghambat tiap-tiap tindakan negara. Caesaro-papisme hanyalah dapat membesarkan negeri, makanala kaisarpaus atau sultan khalifah itu satu tokoh yang kuat dan mutlak. Caesaro-papisme hanyalah dapat menguatkan negara, kalau kaisar-paus atau sultan khalifah itu adalah sungguhsungguh seorang diktator, seorang cakrawati seperti Peter de Groot, seperti Salim I atau 
Muhammad II, seperti Ibnu Saud, seperti

Nebukadnezar, yang zonder banyak omong

lagi ia sendirilah menetapkan tiap-tiap

tindakan negara caesaro-papisme yang

demikian ini sebenarnya tak ubahnyalah

dalam pemerintahan tiap-tiap diktatur

Mussolini atau diktatur Stalin, diktatur Jengis

Khan atau diktatur Hitler. Caesaro Papisme

yang demikian itu menjadi satu hal

kepribadian, satu hal persoon lijke figuur, satu

hal kekuatannya dan kebersiannya seorang

yang menjadi kaisar-paus atau sultan khalif

...56)

Menurut Soekarno, tindakan Kemal menghapuskan kekhalifahan Utsmani, karena sistem itu tidak sesuai dengan "Islam sejati" yang menghendaki adanya "reliugiuse demokratie" (demokrasi berdasarkan agama). Bahwa kini, imbuh Soekarno, bukan jamannya lagi berfikir apologetik tentang adanya satu khalif Islam, karena sekarang eranya kebangsaan, era nasionalisme ; yakni, masing-masing bangsa Islam membentuk negara sendiri-sendiri, masing-masing bangsa Islam ikut panggilan kebangsaannya sendirisendiri. ${ }^{57)}$ "Internasionalisme Islam telah surut, digantikan oleh nasionalisme di negerinegeri kaum muslimin, maka bagaimanakah di jaman nasionalisme ini mungkin diadakan khalifah-khalifah yang syarat batinnya adalah internasionalisme" ${ }^{58)}$

Pada akhirnya Soekarno menutup pemikiran politiknya dengan menekankan arti penting seluruh bangsa Indonesia berfikir tentang masa depan bangsa dan negaranya, include di dalamnya persoalan bagaimana bentuk, visi dan misi negara Indonesia. "Siapa yang tidak insyaf", kata Soekarno, "akan pentingnya soal ini, siapa tidak ara rasa sejarah setetespun di dalam ia punya darah, dia tidak ada 'historisch instinct' sebesar kuman ia punya jiwa ... ${ }^{59)}$ Kemudian dengan bersemangan, Soekarno, mengajak orangorang pandai dan bijak di seluruh negeri untuk berdebat tentang masalah ini. Akhirnya, tanpa memberikan penilaian akhir terhadap tindakan Kemal Attaturk, Soekarno menyatakan:

"Benar atau salahnya ia (Kemal Attaturk: pen.) punya perbuatan hebat bagi Islam, itu sebenarnya bukan kitalah yang dapat menjadi hakim. Yang dapat menjadi hakim baginya, hanyalah sejrah kelak di kemudian hari! Sejarah inilah yang kelah memutuskan: Kemal durhaka atau Kemal maha bijaksana". ${ }^{60)}$

Pagi-pagi sekali - setelah Soekarno, secara terbuka dan panjang lebar membeberkan pemikiran politiknya - Muhammad Natsir ${ }^{61)}$, memberikan reaksi balik untuk membendung gagasan-gagasan sekuleristik Soekarno. Bagi Natsir, agama (Islam) tidak dapat dipisahkan dari negara. Ia menganggap bahwa urusan kenegaraan pada pokoknya merupakan bagian integral risalah Islam. Dinyatakan pula bahwa umat Islam mempunyai falsafah hidup atau ideologi seperti kalangan Kristen, Fasis atau Komunis. Natsir lalu mengutip nash al-Qur'an (51:56) yang dianggapnya sebagai dasar ideologi Islam ; "Tidaklah Aku ciptakan Jin dan Manusia melainkan untuk mengabdi pada-Ku”.

Menurut Natsir, kesalahfahaman terhadap negara Islam, negara yang menyatujkan agama dan politik, pada dasarnya bersumber dari kekeliruan memahami gambaran pemerintahan Islam:

"Kalau kita terangkan, bahwa agama dan negara harus bersatu, maka terbayang sudah di mata seorang bahlul (bloody fool) duduk di 
atas singgasana, dikelilingi oleh 'haremnya' menonton tari 'dayang-dayang'. Terbayang olehnya yang duduk mengepalai 'kementrian kerajaan' beberapa orang tua bangka memegang hoga. Sebab beginilah gambaran 'pemerintah Islam' yang digambarkan dalam kitab-kitab Eropah yang mereka baca dan diterangkan oleh guru-guru bangsa Barat selama ini. Sebab umumnya (kecuali amat sedikit) bagi orang Eropa: Chalifah = harem, Islam $=$ poligami" ${ }^{\prime 2}$

Natsir berkata, bila ingin memahami agama dan negara dalam Islam secara jernih, maka hendaknya mampu menghapuskan gambaran keliru tentang negara Islam di atas. Secara implisit Natsir menilai bahwa gambaran "negara Islam" seperti inilah yang terdapat dalam pikiran Soekarno dan Kemal Attaturk.

Turki, Natsir menambah, di masa pemerintahan para sultan dan kekhalifahan Usmaniah terakhir bukanlah negara atau pemerintahan Islam, sebab para pemimpinnya menindas dan membiarkan rakyatnya bodoh dengan memakai Islam dan segala bentuk ibadah-ibadahnya sebagai tameng belaka. Jadi, Islam pada era Utsmaniyah di Turki, tidak pernah bersatu dengan negara sebagaimana diduga Soekarno mapun Kemal Attaturk. Dengan logika demikian, mendukung Soekarno terhadap gagasan pemisahan agama dari negara tidak tepat. ${ }^{63)}$

Menyinggung pemikiran Ali Abd al-Raziq, yang pemikiran politik Islamnya banyak dikutip Soekarno, Natsir membantah dan mempertanyakan pandangan Ali Abd alRaziq. Ia (Natsir) meragukan pendapat ulama al-Azhar itu, bahwa Nabi hanyalah mendakwahkan agama dan tidak menyuruh mendirikan negara. ${ }^{64)}$ Natsir memiliki pandangan sendiri, bahwa Islam dan negara adalah dua entitas religio politik yang menyatu. "Negara bagi kita, bukan tujuan, tetapi alat. Urusan kenegaraan pada pokoknya dan pada dasarnya adalah satu bagian yang tak dapat dipisahkan, satu intergreerent deel dari Islam”. Baginya, sejauh masalah politik, inilah perbedaan utama antara umat Islam dan umat nonIslam. ${ }^{65)}$

Prinsip musyawarah dalam Islam, menurut Natsir, tampaknya tidak selalu identik dengan asas demokrasi. Hal ini terlihat saat Natsir menganggapi pernyataan Soekarno yang menghendaki agar demokrasi dijadikan alternatif jika timbul persoalan tentang berpisahnya agama dan negara. Natsir mengemukakan bahwa "Islam anti istibdad (despotisme), anti absolutisme, dan kesewenang-wenangan”. Akan tetapi ini tidak berarti, bahwa bahwa dalam pemerintahan Islam itu semua urusan diserahkan kepada keputusan musyawarah Majlis Syura. Dalam parlemen negara Islam, yang hanya boleh dimusyawarahkan adalah tata cara pelaksanaan hukum Islam, tetapi bukan dasar pemerintahannya ${ }^{66}$

Natsir mengakui, demokrasi itu baik, tetapi sistem kenegaraan Islam tidaklah mengandalkan semua urusannya kepada instrumen demokrasi, sebab demokrasi tidak kosong dari berbagai bahaya yang terkandung di dalamnya. Ia menyatakan, bahwa perjalanan demokrasi dari abad ke abad telah memperlihatkan beberapa sifatnya yang baik. Akan tetapi demokrasi juga melakat pada dirinya pelbagai sifat-sifat berbahaya. Dengan tegas pula Natsir mengemukakan, "Islam adalah suatu pengertian, suatu paham, suatu begrip sendiri, yang mempunyai sifat-sifat 
sendiri pula. Islam tak usah 'demokrasi 100\%, bukan pula otokrasi 100\%', Islam itu yah ... Islam". ${ }^{67)}$

Dengan pandangan kebangsaan dan kenegaraan yang seperti itu, Natsir lebih lanjut berpendapat bahwa kemerdekaan bukanlah tujuan akhir gerakan-gerakan Islam. Sebaliknya kemerdekaan harus dipandang tidak lebih dari tujuan antara untuk mencapai ridha Allah. Hal ini harus dilakukan dengan cara menjadikan Islam sebagai hukum di tanah air ini. Dan sejalan dengan itu, ia menyatakan, bahwa "orang Islam tidak akan berhenti hingga itu (kemerdekaan), melainkan akan melanjutkan perjuangannya, selama (negara) belum didasarkan dan diatur menurut susunan hukum kenegaraan Islam”. ${ }^{68)}$

Polemik Soekarno dan Natsir masih bersifat eksploratif. Sejak semula keduanya tidak bermaksud untuk merumuskan konsepkonsep yang siap pakai mengenai hubungan antara agama dan negara. Namun keduanya juga tidak bermaksud untuk menemukan titik temu (kalimah sawa') di antara mereka. Keduanya hanya ingin menunjukkan posisiposisi ideologis-politis masing-masing.

Akibatnya, perdebatan-perdebatan itu hanya menggarisbawahi berbagai perbedaan yang tampaknya tak terjembatani antara kedua kelompok politik yang berseberangan.

Mewakili kelompok nasionalis sekuler, Soekarno kurang berhasil memberi substansi keagamaan terhadap pandangannya mengenai hubungan Islam dan negara yang mengalami "dekonfessionalisasi". Karena itu, meskipun mengimplikasikan paham kaitan non-formal atau etis antara Islam dan negara, dalam pandangan banyak aktivis Islam politik, konsepnya sangat dibayang-bayangi oleh semangat "sekulerisme" Kemal Attaturk, yang disebut dengan nada pejoratif sebagai pemisahan Islam dari negara. ${ }^{69)}$

Di pihak lain, tanggapan-tanggapan Natsir tampaknya tidak cukup matang. Jawabanjawabannya terhadap tantangan-tantangan Soekarno kurang berhasil mengartikulasikan secara bermakna watak dan bentuk politik antara Islam dan negara. Malah, ia berhenti pada pernyataan-pernyataan normatif dan umum mengenai Islam yang mungkin mempengaruhi model kaitan antara kedua aras religio-politik ini. Atau, sebagaimana dinyatakan oleh Deliar Noer, "karena posisinya yang bersifat defensif, karya-karya Natsir sebagian besarnya bercorak apologetik". ${ }^{70)}$

Dengan kedatangan pasukan militer Jepang di kepulauan Nusantara pada 1942, polemik Soekarno dan Natsir untuk sementara terhenti. Tetapi perseteruan politik antara kedua kelompok di atas tetap berlangsung.

\section{Era pendudukan Jepang: Bersatu untuk Kemerdekaan}

Era pendudukan Jepang hanya berlangsung tiga tahun, dari Maret 1942 sampai Agustus 1945. terlepas dari masanya yang singkat, sebagaimana dicatat Benda ${ }^{71}$, masa pendudukan Jepang ini adalah sebuah episode traumatis yang amat mempengaruhi banyak aspek kehidupan masyarakat Indonesia. Bagi kelompok-kelompok Islam, masa singkat itu memberi kesempatan yang jauh lebih besar untuk memperkuat basis sosialpolitik mereka. Bahkan, seperti dikatakan Daniel S. Lev, dalam masa pendudukan Jepang itu, para pemimpin Islam memperoleh kesempatan untuk merebut kembali apa yang telah hilang dari mereka pada 1920-an dan 1930-an, mungkin lebih, 
dan mendesak pemerintah militer Jepang untuk memulihkan hak-hak umat Islam. ${ }^{72)}$ Tapi penting untuk dicatat, bahwa hal itu berlangsung tidak tanpa halangan dari kelompok-kelompok nasionalis, yang terbukti berhasil mementahkan desakan-desakan di atas, hampir di setiap kesempatan. ${ }^{73)}$

Meski demikian, kelompok-kelompok Islam berhasil meraih beberapa keuntungan. Tidak seperti pemerintah kolonial Belanda, pemerintah kolonial Jepang mengaliansikan diri mereka dengan para pemimpin Islam dengan tujuan memenangkan perang. Selain itu mereka tampak lebih bersedia untuk memberi konsesi-konsesi terhadap tuntutan kelompok-kelompok Islam, bukan kelompokkelompok nasionalis, apalagi kelompok aristokrat, priyayi. ${ }^{74)}$ Konsesi-konsesi di atas mencakup; (1) pembentukan Kantor Urusan Agama (Shumubu); (2) pembentukan Majlis Syura Muslimin Indonesia (Masyumi); (3) pembentukan Hizbullah, organisasi militer untuk para pemuda Islam. ${ }^{75)}$

Secara keseluruhan, tampaknya cukup tepat jika disimpulkan bahwa masa pendudukan Jepang telah memperkuat posisi kelompok-kelompok Islam. Pada tingkat yang lebih kongkret, masa itu telah memberikan banyak pengalaman organisasi kepada para pemimpin Islam dalam mengatur masalahmasalah keagamaan. Ketika membandingkan situasi Islam pada dua periode kolonialisme yang berbeda (Belanda dan Jepang), Abikusno Tjokrosujono menyatakan bahwa: "Kebijakan pemerintah Belanda telah memperlemah posisi Islam. Islam tidak memiliki para pegawai di bidang agama yang terlatih di masjid-masjid atau pengadilanpengadilan Islam. Belanda menjalankan kebijakan yang memperlemah posisi Islam. Ketika pasukan Jepang datang, mereka menyadari bahwa Islam adalah suatu kekuatan di Indonesia yang dapat dimanfaatkan". ${ }^{76)}$

Tetapi pada akhirnya, sejalan dengan semakin mengendurnya upaya-upaya strategis Jepang untuk memenangkan perang (dan karenanya membuka lebih lebar pintu menuju kemerdekaan), pemerintah kolonial Jepang mengubah arah kebijakan mereka. Pemerintah Jepang, makin banyak memberikan dukungan kepada para pemimpin kubu nasionalis. Dalam hal ini, cukup aman jika dikatakan, bahwa pemerintah kolonial Jepang lebih mempercayai kelompok nasionalis untuk memimpin negara Indonesia masa depan. Dansejalan dengan itu, beberapa badan dan komite negara yang penting, yang dibentuk untuk mempersiapkan kemerdekaan Indonesia, diserahkan kepada para pemimpin kelompok nasionalis. Itu termasuk Dewan Penasehat (Sanyo Kaigi) ${ }^{77)}$ dan Badan Penyelidik Usaha-Usaha Persiapan Kemerdekaan Indonesia - Dokuritsu Zyunbi Tyoosakai - (BPUPKI). ${ }^{78)}$

Dalam berbagai pertemuan di kedua badan tersebut, perseteruan antara kedua kubu (Islam dan nasionalis) kembali berlangsung. Sejauh mengenai corak hubungan antara Islam dan negara, tampak jelas bahwa mereka mengikuti model penalaran yang sama sebagaimana yang telah diartikulasikan satu dekade sebelumnya. Kelompok Islam yang saat itu dipelopori oleh Ki Bagus Hadikusumo, Abdul Kahar Muzakkir, Abikusno Tjokrosujoso, dan A. Wahid Hasyim, pada intinya berpandangan bahwa, karena posisi Islam di Indonesi begitu mengakar, maka negara harus didasarkan kepada Islam. Di pihak lain berdiri kubu 
nasionalis, yang dipelopori oleh Soekarno, Hatta, dan Supomo, yang membela pandangan bahwa, untuk mempertahankan kesatuan bangsa, maka watak negara harus di-dekonfessionalisasi (meskipun sama sekali tidak berarti tidak religius)

Tetapi, berbeda dari perdebatanperdebatan sebelumnya yang khususnya menyoroti tema-tema umum mengenai hubungan idiologis dan politis antara Islam dan negara, dalam berbagai pertemuan Dewan Penasehat dan BPUPKI, pembahasan yang berlangsung meliputi juga maslahmaslah mendetail yang dipandang relevan dengan pembentukan baik negara Islam maupun negara-negara yang sudah di"dekonfessionalisasi". Hal ini mencakup perdebatan-perdebatan mengenai dasar ideologi dan konstitusi negara; apakah presiden harus seorang muslim atau tidak; apakah Islam harus menjadi agama negara atau tidak; apakah negara harus memiliki aparat-aparat dan badan-badan yang relevan untuk menerapkan hukum-hukum Islam; dan mengenai kemungkinan hari Jum'at dijadikan sebagai hari libur nasional. Tidak ada yang terlalu istimewa dalam semua perkembangan ini, kecuali bahwa para elite politik yang terlibat - baik dari kelompok Islam maupun kelompok nasionalis - pada tahap ini mulai merasakan betapa kemerdekaan Indonesia merupakan sesuatu yang sangat mungkin dicapai. ${ }^{79)}$ Di sinilah berbagai pandangan yang berbeda di antara dua kubu yang selama ini "bertikai", menemukan titik singgung yang sangat romantis.

\section{KESIMPULAN}

Polemik berkepanjangan antara kelompok Islam dan nasionalis disamping bersifat eksploratif pada awalnya, tetapi pada akhirnya mengarah juga kepada perjuangan real konsesi-konsesi politik yang masih berbasis pada tema-tema perdebatan awal, yakni hubungan agama (Islam) dan negara dengan berbagai derivasinya. Pada perdebatan jilid I (era kolonial Belanda sampai kedatangan Jepang di Nusantara), keduanya hanya ingin menunjukkan posisiposisi ideologis-politis masing-masing. Akibatnya, perdebatan-perdebatan itu hanya menggarisbawahi berbagai perbedaan yang tampaknya tak terjembatani antara kedua kelompok politik yang berseberangan. Pada saat itu, mewakili kelompok nasionalis sekuler, Soekarno kurang berhasil memberi substansi keagamaan terhadap pandangannya mengenai hubungan Islam dan negara yang mengalami "dekonfessionalisasi". Karena itu, meskipun mengimplikasikan paham kaitan non-formal atau etis antara Islam dan negara, dalam pandangan banyak aktivis Islam politik, konsepnya sangat dibayang-bayangi oleh semangat "sekulerisme" Kemal Attaturk, yang disebut dengan nada pejoratif sebagai pemisahan Islam dari negara.

Di pihak lain, tanggapan-tanggapan Natsir (mewakili kelompok Islam) tampaknya tidak cukup matang. Jawaban-jawabannya terhadap tantangan-tantangan Soekarno kurang berhasil mengartikulasikan secara bermakna watak dan bentuk politik antara Islam dan negara. Malah, ia berhenti pada pernyataanpernyataan normatif dan umum mengenai Islam yang mungkin mempengaruhi model kaitan antara kedua aras religio-politik ini. Mungkin karena posisinya yang bersifat defensif, pemikiran Natsir dan pemimpin Islam lainnya sebagian besarnya bercorak apologetik-skripturalistik.

Pada pergulatan kubu Islam versus kubu 
nasionalis jilid II, yakni pada era pemerintah kolonial Jepang sampai proklamasi kemerdekaan RI tahun 1945, dengan mengusung isu dan landasan argumen yang hampir sama dalam perdebatan jilid I, kelompok Islam, cukup adil jika dikatakan telah mengalami kekalahan pertama dalam upaya merealisasikan gagasan mereka untuk mengaitkan hubungan Islam dan negara secara legalistik dan formalistik. Kekalahan itu tampak dari tidak dicantumkannya secara keseluruhan - di situ ada salah satu diktum yang berbunyi:”..kewajiban menjalankan syari'at Islam bagi pemeluk-pemeluknya”, yang menjadi ikon perjuangan kelompok Islam - dalam rumusan Pancasila sebagai dasar negara yang resmi.

\section{CATATAN AKHIR}

1 Istilah dekonfessionalisasi diperkenalkan dan dikembangkan sebagai sebuah pendekatan dalam kajian sejarah politik di Indonesia oleh C.A.O. Van Nieuwenhuijze. Istilah ini (dekonfessionalisasi) pada mulanya digunakan di Belanda untuk menunjukkan bahwa, agar dapat menyelenggarkan suatu pertemuan tertentu, wakil-wakil dari berbagai kelompok peribadatan akan menyepakati sebuah landasan bersama (yang dirumuskan bersama), yakni tentang persetujuan bahwa implikasi-implikasi tertentui dari sejumlah (doktrin) peribadatan mereka akan dihindari sebagai topik pembicaraan. Lihat: C.A.O. Van Niuwenhuijze, "Islam and National Self-realization in Indonesia", dalam Cross-Cultural Studies, The Hague: Monton and Co., 1963, h. 152 dikutip dari Bahtiar Effendy, Islam dan Negara, Transformasi Pemikiran dan Praktik Politik Islam di Indonesia (Jakarta: Paramadina, 1998), h. 25

2 Lihat misalnya pandangan pragmatis William James tentang agama dalam The Varietes of Religious Experience (New York: The New American Library, 1960), h. 328

3 Ernest Renan, Apakah Bangsa Itu?, terj. Sunaryo (Jakarta: Erlangga, 1968), h.34

4 Goerge Mc. Kahin, Nationalism and Revolution In Indonesia (Ithaca: Cornell University, 1970), h. 37

5 Ahmad Suhelmi, Polemik Negara Islam, Soekarno Versus Natsir (Jakarta: Teraju, 2002), h. 2

13 Lihat misalnya Robert W. Hefner, Civil Islam: Islam dan Demokratisasi di Indonesia, penterj. Ahmad Baso,
Jakarta: Institut Studi Arus Informasi (ISAI) dan The Asia Foundation (TAF), 2001, h. 76. Bandingkan dengan Albert Hourani, A History of the Arab People (Cambridge: Harvard University Press, 1991), h. 343-349

14 Lihat John L. Esposito, "Muhammad lqbal and the Islamic State", dalam John L. Esposito (ed)., Voices of Resurgent Islam (New York dan Oxford: Oxford University Press, 1983), h. 175-190. Dikutip dari Robert W. Hefner, Civil Islam ... h. 76

15 Ibid., h. 77

16 Goerge Mc. Kahin, Nationalism dan Revolution ... h. 38.

17 Lihat Bahtiar Effendy, Islam dan Negara ... h. 63.

18 Robert W. Hefner, Civil Islam ... h. 77-78.

19 Di bawah kepemimpinan H.O.S. Tjokroaminoto, Abdul Salim, dan Abdul Moeis, SI adalah organisasi pertama yang mengembangkan "pengembangan program politik yang menuntut pemerintahan sendiri (oleh rakyat Indonesia)" dan "kemerdekaan penuh". Lihat Goerge Mc. Kahin, Nationalism and Revolution... h. 65-77; dan Harry J. Benda, The Crescent and the Rising Sun... h. 4277.

20 Menurut Kahin, selama empat tahun sejak kelahirannya, SI telah berhasil merekrut sebanyak 360.000 anggota. Pada 1919, jumlah itu sudah mencapai hampir setengah juta. Lihat Goerge Mc. Kahin, Nationalism and Revolution... h. 65-66

21 Harry J. Benda, The Crescent and the Rising Sun ... h. 4142.

22 Bahtiar Effendy, Islam dan Negara ... h. 64.

23 Lihat Dalier Noer, The Modernist Muslim Movement in Indonesia 1900 - 1942 (Oxford, New York and Jakarta: Oxford University Press, 1978), h. 119-126.

24 Lihat Robert W. Hefner, Civil Islam ... h. 78.

25 Fred R. von der Mehden, "Islam and Rice of Nationalism in Indonesia", h. 139-156.

26 Pada Konggres SI keenam di Surabaya tahun 1921, faksi Marxis dikeluarkan dari organisasi dengan alasan bahwa mereka melanggar disiplin partai karena mempertahankan double keanggotataan; di SI dan PKI. Lihat Dalier Noer, The Modernist Muslim Movement in Indonesia, h. 125.

27 Robert W. Hefner, Civil Islam... h. 78.

28 Goerge Mc.T.Kahin, Nationalism and Revolution in Indonesia .. h. 90

29 Goerge Mc.T.Kahin, Nationalism and Revolution in Indonesia .. h. 90

30 Terlepas dari apakah kategori yang pas untuk dua kelompok itu adalah agama atau politik, para pengamat lebih cenderung memandang kedua kelompok ini dalam kategori-kategori agama, dengan mengganti istilah "Islam" dan "nasionalis" dengan "santri" (muslim yang taat) dan "abangan (muslim yang kurang taat). Karena itulah mereka memandang, misalnya, Muhammad Natsir sebagai santri dan Soekarno sebagai abangan. 
31 Lihat Ahmad Mansur Suryanegara, Menemukan Sejarah: Wacana Pergerakan Islam di Indonesia, Bandung: Mizan, 1995, h. 216.

32 Lihat Robert W. Hefner, Civil Islam ... h. 81-82.

33 Kelahiran NU yang beralaskan tikar politik dapat dielaborasi lebih jauh dari bukunya Ahmad Mansur Suryanegara, Menemukan Sejarah... H. 223-231.

34 Snouck Hurgronje adalah salah satu agen kolonial untuk menciptakan kondisi agar potensi gerakan Islam yang besar menjadi ke arah non-politik, yakni dengan menciptakan kondisi-kondisi konflik antara berbagai organisasi Islam. Lihat Ibid., h. 229.

35 Ibid., 230

36 MT. Arifin, Muhammadiyah Potret yang Berubah, Surakarta: Institut Gelanggang Pemikiran Filsafat, Sosial, Budaya dan Pendidikan, 1990, h. 115.

37 Kategori reformis dan ortodoks untuk menjelaskan posisi Muhammadiyah dan NU dikutip dari Harry ]. Benda, The Crescent and the Rising Sun ... h. 119.

38 Lihat Harry J. Benda, The Crescent and the Rising Sun ...h. 120-122.

39 Harry J. Benda, The Crescent and the Rising Sun ... h. 130.

40 Fadjar Asia, 8 dan 20 Agustus 1928. Dikutip dari Dalier Noer, The Modernist Muslim Movement in Indonesia ... h. 253

41 Soekarno, Di Bawah Bendera Revolusi (Jakarta: Panitia di Bawah Bendera Revolusi, jilid I, 1964), h. 34.

42 Deliar Noer, The Modernist Muslim in Indonesia ... $\mathrm{h}$. 253-257.

43 Deliar Noer, The Modernist Muslim in Indonesia ... h. 253-257.

44 Deliar Noer, The Modernist Muslim in Indonesia ... h. 259.

45 Pandji Islam, Vol (, No.4, 23 Januari 1939. Dikutip dari Ibid., h. 276

46 Ibid., h. 260-263.

47 Benedict R. O'G. Anderson, Imagineed Community: Reflections on the Origin and Spread of Nationalism, London: Vergo, 1991, h. 105

48 Robert W. Hefner, Civil Islam ... h. 79.

49 Soekarno mengajukan pandangan ini dalam tulisan, "Apa Sebab Turki Memisah Agama dan Negara", dalam Soekarno, Di Bawah Bendera Revolusi ... h. 404-407.

49 Ali Abd al-Raziq, al-Islam wa Ushul al-Hukm (Beirut: Maktabah al-hayah, 1966), h. 190-195.

50 Ali Abd al-Raziq, al-Islam wa Ushul al-Hukm, h. 45.

51 Mark R.Woodward, (Ed)., Jalan Baru Islam: Memetakan Paradigma Mutakhir Islam Indonesia, Bandung: Mizan, 1998, h. 283-311.

52 Mark R.Woodward, (Ed)., Jalan Baru Islam, h. 283-311.

53 Mark R.Woodward, (Ed)., Jalan Baru Islam, h. 204.

54 Ali Abd al-Raziq, Islam wa Ushul al-Hukm ... h. 133.

55 Soekarno, Di Bawah Bendera Revolusi ... h. 452

56 Soekarno, Di Bawah Bendera Revolusi ... h.432
57 Soekarno, Di Bawah Bendera Revolusi ... h. 437-438

58 Soekarno, Di Bawah Bendera Revolusi ... h. 438

59 Soekarno, Di Bawah Bendera Revolusi ... h. 444

60 Soekarno, Di Bawah Bendera Revolusi ... h. 445

61 Muhammad Natsir, "Arti Agama dalam Negara", dalam Capita Selecta (Jakarta: Bulan Bintang, 1973), h. 436442

62 Muhammad Natsir, "Arti Agama dalam Negara", 438.

63 Muhammad Natsir, "Arti Agama dalam Negara", h. 440

64 Muhammad Natsir, "Arti Agama dalam Negara", h. 443. Lihat juga h. 481-488

65 Muhammad Natsir, "Arti Agama dalam Negara", h. 442

66 Muhammad Natsir, "Arti Agama dalam Negara", h. 452

67 Muhammad Natsir, "Islam 'Demokrasi?" h. 453

68 Deliar Noer, The Modernist Muslim Movement in Indonesia ... h. 276

69 Bahtiar Effendy, Islam dan Negara ... h. 75-81

70 Bahtiar Effendy, Islam dan Negara, h. 82; Deliar Noer, The Modernist Muslim Movement in Indonesia, h. 323

71 Harry J. Benda, The Crescent and the Rising Sun ... h. 198

72 Daniel S. Lev, Islamic Courts in Indonesia: A Study in the Political Bases of Legal Institutions (Berkeley, Los Angeles, London: University of California Press, 1972), h. 34. Dikutip dari Bahtiar Effendi, Islam dan Negara ... h. 82.

73 Bahtiar Effendi, Islam dan Negara ... h. 82.

74 Harry ]. Benda, The Crescent and the Rising Sun ... h. 201.

75 B.J. Bolland, The Struggle of Islam in Modern Indonesia The Hague: Martinus Nijhoff, 1971, h. 9. Dikutip dari Bahtiar Effendy, Islam dan Negara ... h. 83.

76 Daliel S. Lev, Islamic Courts in Indonesia ... h. 34.

77 Berfungsi sebagai "cikal bakal kabinet". Mereka bertanggung jawab mempersiapkan jawaban-jawaban atas pertanyaan-pertanyaan yang diajukan pemerintah kolonia Jepang mengenai barbagai masalah yang berkaitan dengan soal-soal ke-Islam-an. Manurut Lev, sebagian besar dari mereka berasal dari kelompok nasionalis. Lihat karyanya, Islamic Courts in Indonesia ... h. 35 .

78 Hingga Mei 1945, komite ini terdiri dari 62 anggota. Dari jumlah itu, paling hanya 11 orang yang tampaknya mewakili kelompok Islam. Mereka itu termasuk Ki Bagus Hadikusumo, Abdul Kahhar Muzakkir, Agus Salim, KH. Abdul Halim, KH. Masjkur, H. Ahmad Sanusi, KH. Mas Mansur, Abikusno Tjokrosujoso, Dr. Sukiman, KH. A. Wahid Hasyim, dan A. Baswedan. Untuk daftar yang lebih lengkap, lihat Muhammad Yamin, Naskah Persiapan Undang-Undang Dasar 1945, Jakarta: Yayasan Prapanca, 1959, Jilid I dan II, h. 60.

79 Bahtiar Effendy, Islam dan Negara ... h. 85.

\section{DAFTAR PUSTAKA}

Anderson, Benedict R. O'G. 1991. Imagineed Community: Reflections on the Origin and Spread of Nationalism, 
London: Vergo.

Arifin, MT. 1990. Muhammadiyah Potret yang Berubah, Surakarta: Institut Gelanggang Pemikiran Filsafat, Sosial, Budaya dan Pendidikan.

Benda, Harry J. 1958. The Crescent and the Rising Sun ; Indonesian Islam Under The Japanese Uccupation 19421945, The Hague and Bandung: W. Van Hoeve Ltd. . 1965. "Continuity and Change in Indonesian Islam," Asian and African Studies: Annual of the Israel Oriental Studies, Vol.I

Bolland, B.J. 1971. The Struggle of Islam in Modern Indonesia, The Hague: Martinus Nijhoff.

Effendy, Bahtiar. 1998. Islam dan Negara, Transformasi Pemikiran dan Praktik Politik Islam di Indonesia, Jakarta: Paramadina.

Esposito, John L. 1983. "Muhammad Iqbal and the Islamic State", dalam John L. Esposito (ed)., Voices of Resurgent Islam, New York dan Oxford: Oxford University Press.

Hefner, Robert W. 2001 Civil Islam: Islam dan Demokratisasi di Indonesia, penterj. Ahmad Baso, Jakarta: Institut Studi Arus Informasi (ISAI) dan The Asia Foundation (TAF).

Hourani, Albert. 1991. A History of the Arab People. Cambridge: Harvard University Press.

James, William. 1960. The Varietes of Religious Experience, New York: The New American Library.

Jay, Robert. 1963. Religion and Politic in Rural Central Java, New Haven: Southeast Asia Studies, Yale University.Kahin, Goerge Mc. 1970. Nationalism and Revolution In Indonesia, Ithaca: Cornell University.

Lev, Daniel S. 1972. Islamic Courts in Indonesia: A Study in the Political Bases of Legal Institutions, Berkeley, Los Angeles, London: University of California Press.

Ma'arif, Ahmad Syafi'i. 1983. "Islam as The Basic State: A Study of The Islamic Political Ideas as reflected in the Constituent Assembly Debates in Indonesia", Disertasi Doktor. The University of Chicago.

Natsir, Muhammad. 1973. "Arti Agama dalam Negara", dalam Capita Selecta, Jakarta: Bulan Bintang.

Niuwenhuijze, C.A.O. van. 1963. "Islam and National Selfrealization in Indonesia", dalam Cross-Cultural Studies. The Hague: Monton and Co.

Noer, Deliar. 1978. The Modernist Muslim Movement in Indonesia 1900 - 1942, Oxford, New York and Jakarta: Oxford University Press.

Raziq, Ali Abd al-. 1966.al-Islam wa Ushul al-Hukm, Beirut: Maktabah al-Hayah.

Renan, Ernest. 1968. Apakah Bangsa Itu?, terj. Sunaryo, Jakarta: Erlangga.

Soekarno. 1964. Di Bawah Bendera Revolusi, Jakarta: Panitia di Bawah Bendera Revolusi, jilid I.Suhelmi, Ahmad. 2002. Polemik Negara Islam, Soekarno Versus Natsir. Jakarta: Teraju.

Suminto, H.A. 1982. Politik Islam Hindia Belanda, Jakarta: LP3ES.
Suryanegara, Ahmad Mansur. 1995. Menemukan Sejarah: Wacana Pergerakan Islam di Indonesia. Bandung: Mizan.

Woodward, Mark R. (ed). 1998, Jalan Baru Islam: Memetakan Paradigma Mutakhir Islam Indonesia, Bandung: Mizan.

Yamin, Muhammad. 1959Naskah Persiapan Undang-Undang Dasar 1945, Jakarta: Yayasan Prapanca, Jilid I dan (. 